\title{
ANALISIS RATIO PROFITABILITAS PADA PT. BANK PERKREDITAN RAKYAT JORONG KAMPUNG TANGAH PARIAMAN
}

\author{
Sukra Ilhami, Doni Marlius \\ Akademi Keuangan dan Perbankan \\ Sukrailhami2206@gmail.com
}

\begin{abstract}
This study aims to analyze the financial data held by PT. BPR Jorong Kampung Kampung to see what level of efficiency and effectiveness of the company in carrying out its operational activities in obtaining profits. The profit rate is assessed using profitability ratios namely ROA (Return on assets), ROE (Return on equity), BOPO (operating costs to operating income) and NPM (Net profit margin). The data used are secondary data that is taken from the balance sheet and lab loss report obtained from the documentation of PT. BPR Jorong in the middle of Pariaman in the 2017-2018 period. Based on profitability analysis that ROA, ROE and NPM have decreased while BOPO has increased, due to increased costs incurred by banks so that the income earned is small. The result is that the bank is quite stable in carrying out its activities within the company.
\end{abstract}

Keyword: Return on asset,Return on equity, BOPO, NPM, Profitability

\section{PENDAHULUAN}

Pengukuran efektifitas dan efesiensi manajemen perusahaan bisa dilihat dari laba yang dihasilkan terhadap penjualan dan investasi yang dilihat dari berbagai laporan keuangan yang ada. Semakin tinggi nilai ratio maka semakin baik kondisi perusahaan berdasarkan ratio profitabilitas yang dimiliki. Fintech sangat berpengaruh dalam pendapatan perusahaan terutama perbankan. Keuntungan yang didapat oleh bank bisa saja turun secara drastis dengan adanya fintech, karena maraknya perkembangan teknologi financial atau di Indonesia yang disebut dengan (tekfin).

Perkembangan dunia perbankan di Indonesia saat ini semakin kompetitif, yang menuntut setiap Perbankan lebih profesional lagi. Perbankan juga dihadapkan dengan perkembangan ilmu pengetahuan dan teknologi yang sangat pesat, dimana manusia saat ini dapat mengakses informasi dengan sangat cepat, dapat mengakses infomasi yang terkini, mempermudahkan kita dalam menyelesaikan pekerjaan dengan cepat dan efisien dan melakukan semua transaksi pembayaran dengan fitur layanan elekronik. Salah satu perkembangan technology dibidang keuangan adalah Fintech (Financial Technology).

Menurut (Ansori, 2019) Financial Technology adalah gabungan antara jasa keuangan dengan teknologi yang akhirnya semua kegiatan bisnis dari konvensional 
menjadi moderat, yang awalnya lalu lintas pembayaran yang awalnya harus bertatap muka dan membawa sejumlah uang kas, kini dapat dilakukan dengan jarak jauh dengan hitugan detik saja. Fintech merupakan salah satu inovasi di bidang financial yang mengacu pada teknologi modern bertujuan untuk memperkenalkan kepraktisan, kemudahan akses, kenyaman dan biaya ekonomis.

Latar belakang munculnya fintech yaitu ketika adanya masalah dalam masyarakat yang tidak dapat dilayani oleh industri perbankan dalam melayani masyarakat di daerah tertentu. Jadi masyarakat yang jauh dari akses perbankan belum bisa terlayani oleh perbankan. Hal ini menyebabkan perkembangan ekonomi yang tidak merata. Dengan demikian masyarakat terpencil bisa menggunakan layanan keuangan yang berbasis teknologi tanpa menempuh jarak yang jauh untuk mendapatkan layanan keuangan.

Fintech sangat berpengaruh dalam pendapatan perusahaan terutama perbankan. Keuntungan yang didapat oleh bank bisa saja turun secara drastis dengan adanya fintech, karena maraknya perkembangan teknologi financial atau di Indonesia yang disebut dengan (tekfin). Berkurangnya nasabah yang dimiliki membuat pendapatan perusahaan atau bank tentu akan berkurang juga. Sebab dengan fintech masyarakat dapat melakukan peminjaman dan pendanaan. Peminjaman dengan syarat hanya foto KTP saja, tentu memudahkan masyarakat, masyarakat tidak perlu menyiapkan persyaratan yang banyak seperti di bank- bank pada umumnya, apalagi menyiapkan jaminan-jaminan untuk melakukan peminjaman. Apabila masyarakat telah beralih ke fintech, maka akan berkurannya pendapatan suatu bank. Karena kurangnya peminjaman yang dilakukan masyarakat kepada bank. Oleh karena itu, jika pendapatan yang diperoleh suatu bank berkurang, maka laba yang akan diperoleh tentu saja berkurang juga. Sebab sedikitnya pendapatan yang diterima oleh perusahaan.

Kesehatan bank dapat diartikan sebagai kemampuan suatu bank untuk melakukan kegiatan operasional dengan normal dan mampu memenuhi kewajiabn bank tersebut dengan baik dengan cara cara yang sesuai dengan peraturan perbankan yang berlaku. Kemampuan tersebuat bisa kita liat dari kemampuan menghimpun dana, kemampuan mengelola dana,kemampuan menyalurkan dana kepada masyarakat, kemampuan memenuhi kewajibannya kepada pihak lain dan pemenuhan peraturan yang ada yang berlaku bagi perbankan di Indonesia.

\section{LANDASAN TEORI PengertianBank}

Dalam kehidupan dan pembicaraan sehari- hari, bank dikenal dengan lembaga keuangan yang kegiatan utamanya adalah simpana giro, tabungan dan deposito. Selain itu juga dikenal dengan tempat meminjam uang, menukarkan uang dan temapat pembayaran seperpembayaran listrik, air ,telepon, pajak, uang kuliah dan lainnya.(Nomor 10 tahun 1998 perubahan atas undang undang nomor 7 tahun 1992, 1998) bank adalah badan usaha yang menghimpun dana dari masyarakat dalam bentuk simpanan dan menyalurkannya kepada masyarakat dalam bentuk kredit atau 
bentuk lainnya dalam rangka taraf hidup orang banyak.Dari pengertian tersebut dapat dijelaskan bahwa bank adalah perusahaan yang bergerak dalam bidang keuangan , artinya kegiatan perbankan selalu berkaitan dengan keuangan dan tidak terlepas dalam masalah keuangan.

\section{Bank Perkreditan Rakyat (BPR)}

1) Pengertian BPR

Menurut (Agustiningrum, 2013) Bank perkreditan rakyat (BPR) adalah bank yang melaksanakan kegiatan usaha secara konvensional atau berdasarkan prinsip syariah yang dalam kegiatannya tidak memberikan jasa dalam lalu lintas pembayaran. Artinya Bank perkreditan rakyat jauh lebih sempit dibandingkan bank umum dari segi kegiatannya.

Kegiatan utama usaha BPR ini ditujukan untuk melayani usaha mikro kecil dan menengah pada masyarakat di daerah - daerah pedesaan dan di kota - kota kecil. Bentuk kegiatan BPR sendiri berupa perseroan terbatas, perusahaan derah ataupun dalam bentuk koperasi.

2) Asas, Tujuan, Fungsi dan sasaran BPR

Tugas dan fungsi serta kegiatan bank perkreditan rakyat (BPR) hamper sama dengan bank umum, tetapi cakupan laynan yang diberikan BPR dibatasi oleh beberapa persyaratan yang tidak boleh dilanggar oleh Bank perkreditan rakyat dan tidak bisa seleluasa kegiatan layanan bank umum. Keterbatasan ini sebenarnya terkait dengan misi pendirian bank perkreditan rakyat itu sendiri. Dalam praktiknya kegiatan BPR meliputi:

a. Menghimpun dana dari masyarakat hanya dalam bentuk simpanan berupa tabungan, deposito berjangka dan bentuk lainnya yang dapat disamakan dalam bentuk kedua tersebut.

b. Menempatkan dana pada sertifikat bank Indonesia (SBI), deposito berjangka atau tabungan pada bank lain.

c. Menyalurkan dana dalam bentuk kredit modal kerja, kredit investasi, seta kredit perdagangan.

d. Menyediakan pembiayaan dan penempatan dana sesuai syariah menurut ketentuan yang berlaku pada bann Indonesia.

Karena keterbatasan yang dimiliki BPR maka terdapat beberapa larangan terhadap praktik bank perkreditan rakyat menurut pasal 14 bank perkreditan rakyat (BPR) yaitu:

a) Menerima simpanan berupa girodan ikut serta dalam kegiatan yan menyangkut giro.

b) Melakukan kegiatan usaha dalam usaha valuta asing.

c) Melakukan penyertaan modal.

d) Asuransi dalam bentuk apapun. 
e) Melakukan usaha lain diluar kegiatan yang diberlakukan.

Tujuan BPR adalah menunjang pelaksanaan pembangunan nasional dalam rangka meningkatkan pemerataan, pertumbuhan ekonomi, dan stabilitas nasional ke arah peningkatan kesejahteraan rakyat banyak. Fungsi BPR sendiri sudah sangat jelas yaitu sebagai badan usaha yang bertugas menghimpun dana dari masyarakat dalam bentuk simpanan (depositi, tabungan, giro) dan menyalurkan dana kepada masyarakat dalam bentuk kredit investasi, kredit modal kerja dan kredit perdagangan.

Sasaran BPR adalah melayani kebutuhan para petani, peternak, nelayan, pedagang, pengusaha kecil, pegawai dan pensiunan, karena sasaran ini belum terjangkau oleh bank umum dan untuk lebih mewujudkan pemerataan layanan perbankan, pemerataan kesempatan berusaha, pemerataan pendapatan, agar mereka tidak jatuh ketangan para petugas uang rentenir.

\section{Laporan Keuangan}

Laporan keuangan merupakan catatan informasi keuangan suatu perusahaan dalam bentuk periode yang mengambarkan kinerja perusahaan tersebut, apakah perusahaan dapat mencapai hasil yang ditergetkan atau tidak, dapat dilihat dilaporan keuangan perusahaan, sebab laporan keuangan adalah dokumen finansial perusahaan yang dimiliki perusahaan yang dapat kita analisis, bagaimana keadaan keuangan perusahaan yaitu keadaan mendapatkan keuntungan atau rugi dalam periode tesebut.

(Afriyeni \& Fernos, 2018) mengatakan bahwa laporan keuangan adalah pokok atau hasil akhir dari suatu proses akuntansi yang menjadi bahan informasi bagi para pemakainya sebagai salah satu bahan dalam proses pengambilan keputusan dan juga dapat menggambarkan indikator kesuksesan suatu perusahaan dalam mencapai tujuan terpentingnya.

Tujuan utama perusahaan adalah mendapatkan keuntungan yang diinginkan, serta kegiatan yang dilkakukan selama ini. Jika perusahaan mendapatkan keuntungan terus meningkat dalam satu periode ke periode berikutnya maka perusahaan dapat dikatakan berhasil dalam tujuan utamanya mendapatkan laba. Apabila perusahaan tidak bisa mencapai target yang diinginkan dalam mencapai laba maka perusahaan gagal mendapatkan hasil yang diinginkan dan besar kemungkinan perusahaan rugi dalam periode tersebut. Adapun jenis jenis laporan keuangan menurut Standa Akutansi Keuangan (SAK) yaitu:

\section{Neraca}

Neraca merupakan laporan keuangan yang dikenal degan istilah balance sheet menggambarkan posisi keuangan suatu bank pada tanggal tertentu. Dalam laporan neraca dapat kita lihat informasi seputar aset, kewajiban dan modal perusahaan secara lengkap dan rinci. 
Aktiva harus seimbang dengan passiva, karena apabila tidak sama atau tidak seimbang maka antara keduanya tidak dikatakan balance. Karena antara aktiva dan passive harus sama keduanya. yang termasuk kedalam aktiva adalah aktiva lancar, aktiva tetap dan aktiva tidak berwujud, sedangkan kewajiban adalah utang ( utang dagang, gaji, pajak, obligasi, pensiundan kewajiban lainnya), dan modal antara lain adalah modal saham, agio saham, laba ditahan, laba tahun berjalan dll sebagainya.

2. Laporan Komitmen dan Kontijensi

Laporan Komitmen dan Kontijensi merupakan suatu ikatan atau kontrak yang berupa janji yang tidak dapat dibatalkan secara sepihak (irrevocable) dan harus dilaksanakan sesuai dengan kesepakatan bersama.

3. Laporan Laba Rugi

Laporan Laba Rugi atau yang dikenal dengan istilah profit and loss statement merupakan laporan keuangan bank yang menggambarkan hasil usaha bank dalam suatu periode tertentu. Laporan laba rugi dapat berfungsi sebagai bahan evaluasi yang membantu manajemen dalam pengambilan keputusan, selain itu laporan laba rugi dapat membantu pemerintah melihat berapa informasi pajak yang harus di bayarkan perusahaan.

Laporan laba rugi memiliki beberapa elemen didalamnya seperti harga pokok produksi, pendapatan, beban, hingga laba atau rugi perusahaan.

4. Laporan Arus Kas

Merupakan laporan atau yang dikenal dengan istilah cash flow menunjukkan semua aspek yang berkaitan dengan kegiatan bank, baik yang berpengaruh langsung atau tidak langsung terhadap kas. Laporan Arus Kas harus disusun berdasarkan konsep kas selama periode laporan. Laporan ini juga dapat menjadi alat pertanggung jawaban berapa arus kas masuk dan berapa arus kas keluar dalam perusahaan.

5. Catatan atau Laporan Kuangan

Merupakan laporan yang berisi catatan tersendiri mengenai posisi devisa netto menurut jenis mata uang dan aktivitas lainnya.

6. Laporan Keuangan Gabungan dan Kosoloasi

Merupakan laporan dari cabang - cabang bank yang bersangkutan, baik yang ada didalam maupn diluae negeri. Sedangkan laporan keuangan kosolidasi merupakan laporan keuangan prusahaan yang bersangkutan dengan anak perusahaan.

\section{Pengertian Profitabilitas}

Ratio keuangan adalah alat yan(Mediana Badria, 2018) digunakan manajemen perusahaan dalam menilai keefektifan kinerja perusahaan atau bank dalam suatu periode tertentu. Pada dasarnya ratio keuangan terdiri dari empat ratio yaitu ratio keuangan likuiditas, aktivitas, solvabilitas dan profitabilitas. 
(Sutrisno, 2014) defenisi ratio profitabilitas adalah kemampuan perusahaan dalam memperoleh laba dengan hubungannya dengan penjualan, total aktiva, maupun modal sendiri. Dengan demikian bagian investor sangat berkepentingan dalam bagian ini, ratio untuk menilai kemampuan perusahaan dalam mencari keuntungan. Ratio ini juga memberikan ukuran penting bagi perusahaan dalam mencapai laba, karena bagaiamanapun tujan utama sebuah perusahaanadalah menginginkan keuntungan.

Ratio profitabilitas berisi angka angka tentang kemampuan perusahaan dalam memperoleh laba (earning) terkait penjualan, aset, dan ekuitas berdasarkan ukuran tertentu. Ratio profitabilitas menggambarkan bagaimana efektifnya perusahaan dalam menjalankan kegiatannya, apakah perusahaan telah dapat menghasilkan laba yang diharapkan atau belum dari kegiatan yang dilakukan. . Dari ratio diatas dapat disimpulkan bahwa ratio profitabilitas adalah ratio yang digunakan untuk mengukur kemampuan dan keberhasilan perusahaaan dalam memperoleh keuntungan.

Bagi perusahaan tujuan utama yang hendak dicapai adalah mendapatkan keuntungan yang diinginkan dari kinerja suatu perusahaan yang mempengaruhi catatan atas laporan keuangan yang harus sesuai dengan standar akuntansi keuangan yang ada. Dalam beroperasi untuk menghasilkan laba tersebut perusahaan menggunakan sumber dana baik sumber dana internal yakni dari modal pemilik dan laba ditahan maupun dari eksternal yakni sumber dana yang berasal dari pinjaman pihak lain (Sutrisno, 2014). kemampuan perusahaan dalam memperoleh laba dalam jenis jenis akuntansi keuangan antara lain adalah Margin Laba Kotor (Gross profit margin), Margin Laba Bersih (Net Profit Margin), Return On Assets (ROA), Return on Equity (ROE), BOPO yaitu analisa beban operasional dengan pendapatan opersional..

Ratio-ratio profitabilitas diperlukan untuk mencatat transaksi keuangan yang di nilai oleh kreditur dan investor bank untuk menilai jumlah keuntungan dalam membayar kewajibannya berdasarkan tingakt pemakaian aset dan sumber lainnya yang di pakai dalam perusahaan sehingga terlihat efesiensi perusahaan. Loyalitas perusahaan dan pelannggan juga penting untuk mendapatkan keuntungan perusahaa (Marlius, 2018).

Efektifitas dan efesiensi manajemen diliht dari hasil laba pada penjualan perusahaan. Nilai yang tinngi menggambarkan perusahan dalam keadaan laba sedangkn jika nilai rendah menggambarkn perusahan dalam mengalami kerugian.

PT. Bank Perkreditan JKT Pariaman merupakan salah satu bank yang berperan memberikan kontribusi aktif bagi keberhasilan pelaksanaan pembangunan khususnya dibidang penyediaan modal bagi masyarakat. Dalam beroperasi untuk menghasilkan laba tersebut perusahaan menggunakan sumber dana baik sumber dana internal yakni dari modal pemilik dan laba ditahan maupun dari eksternal yakni sumber dana yang berasal dari pinjaman pihak lain (Sutrisno, 2014). kemampuan perusahaan dalam memperoleh laba dalam jenis jenis akuntansi keuangan antara lain adalah Margin Laba Kotor (Gross profit margin), Margin Laba Bersih (Net Profit Margin), Return On Assets (ROA), Return on Equity (ROE), BOPO yaitu analisa beban operasional dengan pendapatan opersional. 
Menurut (Afriyeni \& Fernos, 2018) Return on Asset yaitu rasio yang menggambarkan laba perusahaan (earning) yang dihitung oleh manajemen atas total asset atau aktiva yang dimiliki oleh perusahaan. Return On Equity (ROE) merupakan rasio profitabilitas yang menyatakan tingkat pengembalian (return) yang didapatkan oleh manajemen atas modal yang ditanam oleh pemegang saham.

Rasio BOPO sering disebut rasio efisiensi digunakan untuk mengukur kemampuan manajemen bank dalam mengendalikan biaya operasional terhadap pendapatan operasional. Dan (Tompodung, 2014) menyatakan bahwa Net Profit Margin merupakan rasio yang memperlihatkan perusahaan dalam menghasilkan keuntungan bersih setelah di potong pajak.

PT. BPR Jorong Kampung Tangah adalah adalah salah satu bank umum yang kegiatannya tidak terlepas dari bidang keuangan yang harus memperhatikan efektifitas dan efesiensi operasionalnya serta memperhatikan keuntungan yang baik. berikut ini adalah laporan keuangan PT. BPR Jorong Kampung Tangah Periode 2017 dan 2018.

\section{Tabel 1 \\ Data Keuanagan PT. BPR JKT PARIAMAN Periode $2017 \& 2018$}

\begin{tabular}{lcc}
\multicolumn{1}{c}{ Keterangan } & Tahun & (Ribuan Rp) \\
\hline Total aset & $\mathbf{2 0 1 7}$ & $\mathbf{2 0 1 8}$ \\
Modal sendiri & 41.466 .863 & 43.921 .715 \\
Pendapatan operasional & 10.000 .000 & 10.000 .000 \\
& 5.324 .292 & 5.636 .787 \\
Beban operasional & & \\
Laba sebelum pajak & 4.004 .360 & 4.351 .505 \\
Laba bersih & 1.353 .020 & 1.349 .399 \\
\hline \multicolumn{1}{c}{ Berdasarkan tabel 1 dapat dilitat } & 1.111 .239 \\
\hline
\end{tabular}

Berdasarkan tabel 1 dapat dilihat bahwa data awal neraca dan laporan laba rugi PT. BPR JKT PARIAMAN selalu mengalami penurunan tiap tahunnya. Ini diketahui dari perolehan pendapatan dari tahun 2017 (Rp. 5.324.292) dan 2018 (Rp. 5.636.787). Sedangkan untuk perolehan laba bersih mengalami penurunan juga dari tahun 2017 (Rp. 1.119.585) dan tahun 2018 (Rp. 1.111.239).

Dari uraian diatas terlihat bahwa salah satu faktor untuk melihat kondisi serta tingkat keuntungan keuangan bank, sehingga penulis tertarik untuk mengadakan penelitian mengenai analisa tingkat kesehatan keuangan bank dengan menggunakan data laporan keuangan pada PT. BPR JKT Pariaman. Dalam penelitian ini penulis mengambil judul "Analisis Ratio Profitabilitas Pada PT. BPR JKT Pariaman.

Berdasarkan uraian latar belakang masalah diatas, maka rumusan tujuan dalam penelitian ini sebagai berikut adalah bagaimana ratio profitabilitas pada PT. 
BPR JKT Pariaman selama periode tahun 2017-2018 berada dalam kondisi laba dengan menggunakan ratio ROA, ROE, BOPO dan NPM.

\section{METODE PENELITIAN}

Dalam pengumpulan data dan bahan untuk melakukan penelitian ini, penulis menggunakan metode dengan dua cara sebagai berikut : a. Peninjauan Langsung ke Objek yaitu penelitian langsung ke objek penelitian yang dipilih untuk meneliti hasil data primer. Penelitian langsung kelapangan ini akan dapat membantu penulis untuk menambahkan data yang diperlukan. Adapun cara riset lapangan ini yaitu dengan cara mewawancarai langsung pihak terkait dalam hal ini adalah perusahaan atau instansi terkait. b. Studi Keperpustakaan (Lebrary Research) yaitu Penelitian ini dilakukan ke perpustakaan berupa buku-buku ilmiah dan tulisan-tulisan yang berhubungan dengan pembahasan yang dilakukan.

\section{HASIL DAN PEMBAHASAN}

\section{Rasio Return On Asset}

Menurut (Afriyeni \& Fernos, 2018) Return on Asset yaitu rasio yang menggambarkan laba perusahaan (earning) yang dihitung oleh manajemen atas total asset atau aktiva yang dimiliki oleh perusahaan. Rasio ini dipakai oleh bank untuk mengukur kesanggupan manajemen Bank Perkreditan Rakyat dalam mendapatkan keuntungan (laba) secara keseluruhan serta menggambarkan efesiensi kemampuan kerja bank yang bersangkutan dan digunakan untuk mengukur kemampuan bank dalam mengelola seluruh biaya operasional dan non-operasional. BI juga mengisyaratkan bahwa tingkat ROA yang baik suatu perusahaan lebih dari $1,22 \%$. Matriks penilaian tingkat rasio ROA menurut Bank Indonesia (Surat Edaran Bank Indonesia, 2004) adalah sebagai berikut :

Matriks Kriteria Penilaian Tingkat ROA

a. $\mathrm{ROA}>1,5 \%$ Sangat baik

b. $1,25 \%<\mathrm{ROA} \leq 1,5 \%$ Baik

c. $0,5 \%<\mathrm{ROA} \leq 1,25 \%$ Cukup

d. $0 \%<\mathrm{ROA} \leq 0,5 \%$ Tidak baik

e. $0<\mathrm{ROA} \leq 0,5 \%$ Sangant tidak baik

Berdasarkan data yang diperoleh Return On Asset PT. BPR Jorong Kampuang Tangah pada periode 2017 - 2018 ditunjukkan pada tabel dibawah ini. 
Tabel 2

\section{Perhitungan Return On Asset PT. BPR Jorong Kampuang} Tangah Pariaman padaperiode 2017 - 2018

\begin{tabular}{lll} 
& \multicolumn{1}{c}{ (Ribuan Rp) } \\
\hline \multicolumn{1}{c}{ Komponen } & Des 2017 & \multicolumn{1}{c}{ Des 2018 } \\
\hline a. Laba bersih sebelum pajak & 1.353 .020 & 1.349 .399 \\
b. Total Aktiva & 41.46 .863 & 43.921 .715 \\
\hline
\end{tabular}

$$
\text { Sumber : Data diolah }
$$

Dengan formula :

$$
\mathrm{ROA}=\frac{\text { Laba sebelum pajak }}{\text { total asset }} \times 100 \%
$$

a. Desember 2017

b. Desember 2018

$$
\mathrm{ROA}=\frac{1.353 .020}{41.466 .863} \times 100 \%=3.26 \%
$$

$$
\mathrm{ROA}=\frac{1.349 .399}{43.921 .715} \times 100 \%=3.07 \%
$$

Dari ROA PT. BPR Jorong Kampuang Tangah dapat disimpulkan bahwa tahun 2017 sebesar 3.26\%, tahun 2018 sebesar 3.07\%. Berdasarkan perhitungan tersebut dapat disimpulkan ROA PT. BPR jorong kampuang tangah mengalami penurunan. Tetapi walaupun mengalami penurunan keterangan nya adalah baik. Sebab perusahaan bisa memanfaatkan asset dengan baik sehingga menimbulkan keuntungan pada perusahaan. Perusahaan dapat memanfaatkan aset dengan baik dan efisien sehingga menghasilkan ROA yang tinggi pula. Jika perusahaan terus mengalami kenaikan ROA tiap tahunnya maka pendapatan perusahaan akan meningkat sehingga kreditur dan investor akan bertambah karena peningkatan yang baik pada pendapatan perusahaan.

2. Rasio Return On Equity

Menurut (Fernos, 2017) Return On Equity (ROE) merupakan rasio profitabilitas yang menyatakan tingkat pengembalian (return) yang didapatkan oleh manajemen atas modal yang ditanam oleh pemegang saham. Return On Equity menunjukan dari modal sendiri untuk menghasilkan keuntungan bagi pemegang saham preferen dan saham biasa, semakin besar Rasio ini maka semakin baik. Bahwa Return On Equity merupakan rasio yang mengukur kemampuan suatu perusahaan dalam menghasilkan laba bersih dari modal sendiri yang digunakan oleh perusahaan. Menurut standar BI ROE adalah lebih dari $12 \%$ (Baik).

Matriks penilaian tingkat rasio ROE (Surat Edaran Bank Indonesia, 2004) adalah sebagai berikut :Matriks Kriteria Penilaian Tingkat ROE

a. ROE $>23 \%$ Sangat baik

b. $18 \%<\mathrm{ROE} \leq 23 \%$ Baik 
c. $13 \%<\mathrm{ROE} \leq 18 \%$ Cukup

d. $8 \%<\mathrm{ROE} \leq 13 \%$ Kurang baik

e. ROE $\leq 8 \%$ Sangat tidak baik

Sumber : www.bi.go.id

Berdasarkan data Yang diperoleh Return On Equity PT.BPR Jorong Kampuang Tangah Pariaman pada periode 2017 - 2018 ditunjukkan pada tabel dibawah ini.

Tabel 3

Perhitungan Return On Equity PT.BPR Jorong Kampuang Tangah Pariaman pada periode $2017-2018$

(Ribuan Rp)

\begin{tabular}{llll}
\hline \multicolumn{1}{c}{ Komponen } & \multicolumn{1}{c}{ Des 2017 } & \multicolumn{1}{c}{ Des 2018 } \\
\hline a. Laba besih setelah pajak & 1.119 .585 & 1.111 .239 \\
b. Modal sendiri & 10.000 .000 & 10.000 .000 \\
\hline
\end{tabular}

Sumber : data olahan

Dengan formula :

a. Desember 2017

b. Desember 2018

$$
\mathrm{ROE}=\frac{1.119 .585}{10.000 .000} \times 100 \%=11.20 \%
$$

$$
\mathrm{ROE}=\frac{1.111 .239}{10.000 .000} \times 100 \%=11.11 \%
$$

Maka dapat disimpulkan bahwa ROE PT. BPR Jorong Kampuang Tangah tahun 2017 sebesar $11.20 \%$ dan tahun 2018 sebesar $11.11 \%$, Berdasarkan perhitungan tersebut ROE bank ini mengalami penurun. Penilaian persentase Return On Asset nya kurang baik, bank tidak efektif dan tidak efesien serta tidak memanfaatkan modal yang dimilikinya untuk memperoleh keuntungan.

3. Analisis Rasio Beban Operasional dan Pendapatan Operasional

Menurut (Kurniasari, 2017) BOPO adalah Rasio beban operasional diguanakan untuk mengukur perbandingan tingkat efisiensi dan kemampuan bank dalam melakukan kegiatan operasionalnya. Aktivitas ini juga termasuk kedalam pendapatan komisi dan provisi yang diterima dalam pemberian kredit. Matriks penilaian tingkat rasio BOPOn (Surat Edaran Bank Indonesia, 2004) adalah sebagai berikut :

Matriks Kriteria Penilaian Tingkat BOPO
a. $\mathrm{BOPO} \leq 83 \%$ Sangat baik
b. $83 \%<\mathrm{BOPO} \leq 85 \%$ Baik
c. $85 \%<$ BOPO $\leq 87 \%$ Cukup
d. $87 \%<$ BOPO $\leq 89 \%$ Tidak Baik
e. $\mathrm{BOPO} \geq 89 \%$ Sangat tidak baik

Sumber : www.bi.go.id 
Berdasarkan data yang diperoleh Beban Operasional terhadap Pendapatan Operasional Bank (BOPO) PT. BPR Jorong Kampuang Tangah ditunjukkan pada tabel dibawah ini.

\section{Tabel 4}

Perhitungan Biaya Operasional Terhadap Pendapatan Operasional PT. BPR Jorong Kampuang Tangah Periode 2017 - 2018

\begin{tabular}{lll} 
& & (Ribuan Rp) \\
\hline \multicolumn{1}{c}{ Komponen } & Des 2017 & Des 2018 \\
\hline 1. Total Beban Operasional & 4.004 .360 & 4.351 .505 \\
2. Total Pendapatan Operasional & 5.324 .292 & 5.636 .787 \\
\hline
\end{tabular}

Sumber: data olahan

Dengan formula :

$$
\mathrm{BOPO}=\frac{\text { total beban operasaional }}{\text { total pendapatan operasional }} \times 100 \%
$$

a. Desember 20117

b. Desember 2018

$$
\mathrm{BOPO}=\frac{4.004 .360}{5.324 .292} \times 100 \%=75,20 \%
$$

$$
\mathrm{BOPO}=\frac{4.351 .505}{5.636 .787} \times 100 \%=77.20 \%
$$

Dapat kita simpulkan bahwa BOPO PT. BPR Jorong Kampuang Tangah tahun 2017 sebesar 75.20\%, tahun 2018 sebesar 77.20\%. Dari hasil tersebut dapat ditarik kesimpulan bahwa kinerja Bank ini efesien. Karena persentase BOPO tergolong kedalam kriteria sangat baik penilaian BI. Sebab bank bisa menghasilkan persentase di bawah $83 \%$. Jika persentasi BOPO ini semakin kecil maka bank akan semakin tinggi mendapatkan laba, karena bank bisa mengendalikan biaya seefesien mungkin atas operasinal perusahaan yang dilakukan. Jika sebaliknya bank memiliki persentase BOPO yang lebih dari $89 \%$ maka bank dikatakan sangat tidak baik karena banyaknya biaya yang dikeluarkan oleh bank atas operasoinal yang dilakukan. Sehingga keuntungan yang didapatkan oleh bank akan berkurang karena pengeluaran yang banyak tersebut.

4. Rasio Net Profit Margin

(Tompodung, 2014) menyatakan bahwa Net Profit Margin merupakan rasio yang memperlihatkan perusahaan dalam menghasilkan keuntungan bersih setelah di potong pajak. Yakni kontribusi penjualan terhadap laba bersih yang dihasilkan.Rasio ini mengukur sejauh mana kemampuan PT. BPR Jorong Kampuang Tangah dalam mendatangkan laba bersih pada tingkat penjualan/ pendapatan tertentu. Rasio ini bisa tafsirkan juga sebagai kemampuan bank menekan beban-beban perusahaan dalam periode tertentu. Matriks penilaian tingkat rasio NPM (Surat Edaran Bank Indonesia, 2004) adalah sebagai berikut: 
Matriks Kriteria Penilaian Tingkat NPM
a. $N P M \geq 100 \%$ Sangat baik
b. $81 \% \leq \mathrm{NPM}<100 \%$ Baik
c. $66 \% \leq \mathrm{NPM}<81 \%$ Cukup
d. $51 \% \leq \mathrm{NPM}<66 \%$ Tidak baik
e. NPM $<51 \%$ Sangat tidak baik

Sumber : www.bi.go.id

Berdasarkan data yang diperoleh Net Profit Margin PT. BPR Jorong Kampuang Tangah pada periode 2017 - 2018 ditunjukkan pada tabel dibawah ini.

Tabel 5

Perhitungan Net Profit Margin PT. BPR Jorong Kampuang Tangah padaPeriode 2017-2018

\begin{tabular}{llcl} 
& & \multicolumn{1}{c}{ (Ribuan Rp) } \\
\hline \multicolumn{1}{c}{ Komponen } & Des 2017 & \multicolumn{1}{c}{ Des 2018 } \\
\hline 1. Laba bersih setelah pajak & 1.119 .585 & 707.588 \\
2. Total pendapatan operasional & 5.324 .292 & 4.107 .383 \\
\hline
\end{tabular}

Sumber: Data Olahan

Dengan formula:

$$
\mathrm{NPM}=\frac{\text { Laba setelah pajak }}{\text { total pendapatan }} \times 100 \%
$$

a. Desember 2017

$$
\mathrm{NPM}=\frac{1.119 .585}{5.324 .292} \times 100 \%=21.02 \%
$$

b. Desember 2018

$$
\mathrm{NPM}=\frac{1.111 .239}{5.636 .787} \times 100 \%=19.71 \%
$$

Dapat disimpulkan bahwa NPM PT. BPR Jorong Kampuang Tangah tahun 2017 sebessar 21.02\%, tahun 2018 sebesar 19.71\%, Berdasarkan perhitungan tersebut NPM PT. BPR Jorong Kampuang Tangah mengalami penurunan, bahkan ini adalah kondisi yang sangat buruk dalam penilaian kriteria penilaian BI sebab kurang dari 51\%, semakin tinggi Net Profit Margin maka semakin baik ratio ini bagi perusahaan dalam memperoleh laba yang dapat dijadikan ukuran representatif. Keuntungan yang diperoleh tersebut juga harus dibandingkan dengan besarnya jumlah dana untuk mendapatkan laba tersebut Artinya kemampuan bank dalam memperoleh laba dengan pengelolaan biaya operasional bank harus diperhatikan supaya tidak berdampak buruk. 


\section{SIMPULAN}

Gambaran tingkat profitabilitas PT. Bank Perkreditan Rakyat selama periode Desember 2017 - Desember 2018 sebagai berikut :

\section{Tabel 6}

Perbandingan Rasio Profitabilitas

PT. BPR Jorong Kampuang Tangah - Pariaman

Tahun 2017 - 2018

\begin{tabular}{llll}
\multicolumn{1}{c}{ Rasio } & \multicolumn{1}{c}{$\mathbf{2 0 1 7}$} & \multicolumn{1}{c}{$\mathbf{2 0 1 8}$} & \multicolumn{1}{c}{ Tingkat Kesehatan BPR } \\
\hline Return On Assets & $3,2 \%$ & $3.07 \%$ & $\frac{>1,22 \%}{>18 \%}$ \\
Raturn On Equity & $11,20 \%$ & $11,11 \%$ & $\frac{>18 \%}{<93,52 \%}$ \\
Biaya Operasional & $75,20 \%$ & $77,20 \%$ & $\underline{\underline{\Delta 5 \%}}$ \\
Net Profit Margin & $21,02 \%$ & $19,71 \%$ & $\underline{ }$
\end{tabular}

Sumber: Data Olahan

1. Dari ROA PT. BPR Jorong Kampuang Tangah dapat disimpulkan bahwa Desember tahun 2017 sebesar 3.26\% dan Desember tahun 2018 sebesar $3.07 \%$. Berdasarkan perhitungan tersebut dapat disimpulkan ROA PT. BPR jorong kampuang tangah mengalami penurunan. Tetapi walaupun mengalami penurunan keterangan nya adalah baik. Sebab perusahaan bisa memanfaatkan asset dengan baik sehingga menimbulkan keuntungan pada perusahaan. Perusahaan dapat memanfaatkan aset dengan baik dan efisien sehingga menghasilkan ROA yang tinggi pula. Jika perusahaan terus mengalami kenaikan ROA tiap tahunnya maka pendapatan perusahaan akan meningkat sehingga kreditur dan investor akan bertambah karena peningkatan yang baik pada pendapatan perusahaan.

2. ROE PT. BPR Jorong Kampuang Tangah Desember tahun 2017 sebesar $11.20 \%$ dan Desember tahun 2018 sebesar 11.11\%, Berdasarkan perhitungan tersebut ROE bank ini mengalami penurun. Penilaian persentase Return On Asset nya kurang baik, bank tidak efektif dan tidak efesien dserta tidak memanfaatkan modal yang dimilikinya untuk memperoleh keuntungan. Jika perusahaan terus mengalami persentasi kurang dari $12 \%$ secara terus menerus maka pemegang saham dan calon investor akan hilang karena perusahaan tidak dapat memanfaatkan modal sendiri untuk mendapatkan keuntungan pada perusahaan apalagi bank perkreditan rakyat pemegang sahamnya hanya sedikit dibandingkan bank umum. Maka perlu PT. BPR Jorong Kampuang Tangah meningkatkan nilai ROE untuk menarik investor dan pemegang saham dan membuat perusahaan mendapatkan keuntungan yang diinginkan.

3. BOPO PT. BPR Jorong Kampuang Tangah tahun 2017 sebesar 75.20\%, tahun 2018 sebesar 77.20\%. Dari hasil tersebut dapat ditarik kesimpulan bahwa kinerja Bank ini efesien. Karena persentase BOPO tergolong kedalam kriteria sangat baik penilaian BI. Sebab bank bisa menghasilkan 
persentase di bawah $83 \%$. Jika persentasi BOPO ini semakin kecil maka bank akan semakin tinggi mendapatkan laba, karena bank bisa mengendalikan biaya seefesien mungkin atas operasinal perusahaan yang dilakukan. Jika sebaliknya bank memiliki persentase BOPO yang lebih dari $89 \%$ maka bank dikatakan sangat tidak baik karena banyaknya biaya yang dikeluarkan oleh bank atas operasoinal yang dilakukan. Sehingga keuntungan yang didapatkan oleh bank akan berkurang karena pengeluaran yang banyak tersebut.

4. NPM PT. BPR Jorong Kampuang Tangah tahun 2017 sebessar 21.02\%, tahun 2018 sebesar 19.71\%, Berdasarkan perhitungan tersebut NPM PT. BPR Jorong Kampuang Tangah mengalami penurunan, bahkan ini adalah kondisi yang sangat buruk dalam penilaian kriteria penilaian BI sebab kurang dari 51\%, semakin tinggi Net Profit Margin maka semakin baik ratio ini bagi perusahaan dalam memperoleh laba yang dapat dijadikan ukuran representatif. Keuntungan yang diperoleh tersebut juga harus dibandingkan dengan besarnya jumlah dana untuk mendapatkan laba tersebut Artinya kemampuan bank dalam memperoleh laba dengan pengelolaan biaya operasional bank harus diperhatikan supaya tidak berdampak buruk.

\section{UCAPAN TERIMA KASIH}

Penulis mengucapkan terimah kasih kepada: Pimpinan PT. BPR JKT Pariaman yang telah mengizinkan penulis memperoleh informasi, Serta semua pihak yang telah membantu penulis dalam penyelesaian artikel ini.

\section{DAFTAR PUSTAKA}

Afriyeni, A., \& Fernos, J. (2018). Analisis Faktor-Faktor Penentu Kinerja Profitabilitas Bank Perkreditan Rakyat (Bpr) Konvensional Di Sumatera Barat. Jurnal Benefita, 3(3), 325. https://doi.org/10.22216/jbe.v3i3.3623

Badria, M., \& Marlius, D. (2019). Analisis Rasio Likuiditas Pada PT. Bank Perkreditan Rakyat (BPR) Lengayang. https://doi.org/10.31219/osf.io/esvb7

Fernos, J. (2017). Analisis Rasio Profitabilitas Untuk Mengukur Kinerja Pada PT. Bank Pembangunan Daerah Provinsi Sumatera Barat. Jurnal Pundi, 1(2), 107118. https://doi.org/10.31575/jp.v1i2.25

Fitri, H. Y., \& Marlius, D. (2019). Analisis Rasio Likuiditas Pada PT. Bank Perkreditan Rakyat (BPR) Nagari Kasang. https://doi.org/10.31219/osf.io/bcs73

Kasmir, D. (2014). Bank Dan Lembaga Keuangan Lainnya. Edisi Revisi 2014 PT Raja Grafindo Persada Jakarta. 
Kurniasari, R. (2017). Analisis Biaya Operasional Dan Pendapatan Operasional (Bopo) Terhadap Return on Assets(Roa). E-Jurnal Perspektif, 15(1), 8. https://doi.org/10.31294/jp.v15i1.2008

Mustika, S., \& Marlius, D. (2019). Analisa Tingkat Kesehatan Keuangan PT. Bank Perkreditan Rakyat (BPR) Batang Palangki. https://doi.org/10.31219/osf.io/wupyh

Nomor 10 tahun 1998 perubahan atas undang undang nomor 7 tahun 1992. (1998).

Sari, Y. P., \& Marlius, D. (2019). Analisis Rasio Profitabilitas Pada PT. Bank Negara Indonesia Syariah. https://doi.org/10.31219/osf.io/94bwq

Surat Edaran Bank Indonesia. (2004). Surat Edaran Bank Indonesia. CWL Publishing Enterprises, Inc., Madison, 1-11.

Sutrisno. (2014). Pengaruh Profitabilitas Terhadap Kebijakan Dividen dan Nilai Perusahaan. 10(2), 32-48.

Tompodung, O. (2014). Analisis Net Profit Margin Pada Usaha Laundry Di Kota Manado. Emba, 2(2), 9. 